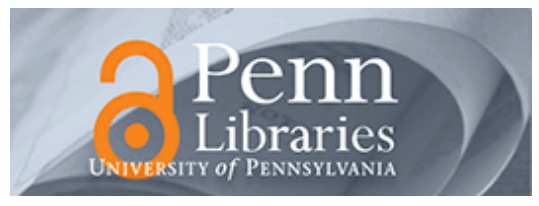

Studies in Visual Communication

Volume 8

Issue 3 Summer 1982

Article 5

1982

\title{
The World Viewed: Works of Nineteenth-Century Realism
}

Marjorie Munsterberg

\section{Recommended Citation}

Munsterberg, M. (1982). The World Viewed: Works of Nineteenth-Century Realism. 8 (3), 55-69. Retrieved from https://repository.upenn.edu/svc/vol8/iss3/5

This paper is posted at ScholarlyCommons. https://repository.upenn.edu/svc/vol8/iss3/5

For more information, please contact repository@pobox.upenn.edu. 


\section{The World Viewed: Works of Nineteenth-Century Realism}




\title{
The World Viewed: Works of Nineteenth-Century Realism
}

\author{
Marjorie Munsterberg
}

The delight bewilders the mind.... If the eye attempts to follow the flight of a gaudy butterfly, it is arrested by some strange tree or fruit; if watching an insect, one forgets it in the strange flower it is crawling over; if turning to admire the splendour of the scenery, the individual character of the foreground fixes the attention. The mind is a chaos of delight.

$$
\text { _Charles Darwin, Journal (1831-1836) }
$$

[With the Illustrated London News] the public will have henceforth under their glance, and within their grasp, the very form and presence of events as they transpire, in all their substantial reality, and with evidence visible as well as circumstantial

$$
\text { - Inaugural editorial, Illustrated London News }
$$

(May 14, 1842, p. 1)

Among the most provocative of the rediscoveries that have been made in nineteenth-century art in recent years are those pictures that employ an uncannily modern style of realism. Sketches, prints, and paintings, by Northern European artists in particular, exhibit a sensitivity to the structure of the pictorial composition and a fascination with the precisely rendered physical object that seem to anticipate works of the 1960s and 1970s. Despite the immediate visual appeal of these images, however, few historians have tried to make sense of the aesthetic they represent. Thus the intellectual challenge of Peter Galassi's Before Photography (1981; reviewed by Snyder 1982), which discussed them within the context of Western artistic traditions, offered special pleasure. It was the stimulation provided by his show and the accompanying catalog that prompted this article.

Marjorie Munsterberg is Associate Curator of Photography at the Canadian Centre for

Architecture.
The challenge as well as much of the charm of these mostly unpretentious, highly detailed depictions of the material world stems from their apparent lack of an appropriate historical context. Despite their plentitude and their ubiquity, the images do not seem to fit comfortably into the art of the nineteenth century. Lack of pictorial ambition and an often frankly illustrative nature bar them from the so-called modernist tradition, a partially self-proclaimed lineage born with the French Revolution and the painter Jacques-Louis David. These artists-Gustave Courbet, Edouard Manet, and Paul Cézanne, among others - form what to later generations became the avant-garde, a status that gave positive meaning to their failure to achieve contemporary critical success. Lack of pictorial ambition, unconventional subject matter, and frequently unorthodox compositions distinguish these works of realism from the art of the Academy, which especially in France filled the major public exhibitions with highly finished, richly detailed narrative pictures. Finally, both medium and purpose remove many of these works from the nineteenth century's vigorous tradition of popular imagery.

The lack of connection to a historically defined context encourages the modern viewer to see these pictures only with modern eyes, appreciating those qualities that accord with the values of the present alone without reference to the past. I will argue that seen within the context of their making, however, these pictures do not express a sensibility peculiarly similar to our own. Rather, they express a host of qualities that characterize the art of the nineteenth century, interests that have been gathered loosely under the rubric "realism." Although usually employed with self-defeating vagueness, the term can be developed with precision, and I believe that such study done on a large scale will provide a broad conceptual understanding of an important kind of nineteenthcentury art. A richly developed set of attitudes can be discovered that encompasses pictures as diverse as prints, photographs, and unpretentious sketches, as well as the ambitious public art of major figures such as Joseph Mallord William Turner, Jean-AugusteDominique Ingres, and Edgar Degas. I hope to offer a small step toward such an understanding here. ${ }^{2}$ 


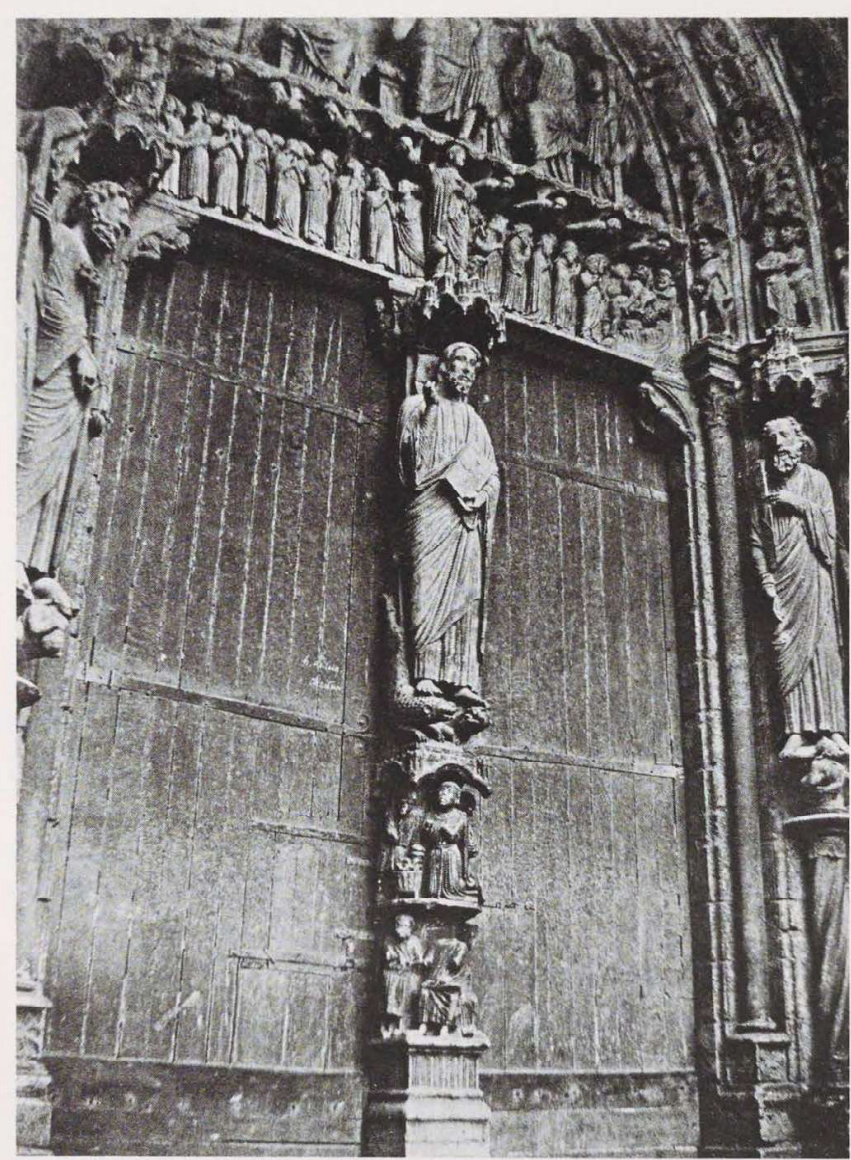

Figure 1 Henri Le Secq. Chartres Cathedral, South Transept Porch, Central Portal, 1852. Photolithograph. (Plate from Fragments d'architecture et sculpture de la cathédrale de Chartres d'après les clichés de $M$. Le Secq, artiste peintre, Paris, late 1870s, from negative made in 1852.) Collection Phyllis Lambert, on loan to the Canadian Centre for Architecture, Montreal.

\section{Nineteenth-Century Notions of Reality}

Sweeping historical generalizations by necessity run roughshod over the subtleties of the very topography which they seek to explicate. Nonetheless, such statements also have the virtue of their breadth: the placement of the given argument within a larger vision, the identification of a premise of the author's point of view. With these limitations firmly in mind, I would like to suggest that a fundamental aspect of the nineteenth century's distinctive brand of realism (not to be confused with the mid-century style of painting, Realism) is an obsessive fascination with the physical world, and more, a craving, an unquenchable thirst, for the direct experience of the tangible and material. It was not enough to read of places or people or things. One had to go, see, absorb, at first hand, and the closer one could get to the originaleven if it was by means of deceptive illusion (a process which offered its own seductive attractions) the better. The Illustrated London News, for example, destined to become one of the most popular magazines of the century, tried to entice readers by promising "the very form and presence of events as they transpire, in all their substantial reality" (May 14. $1842, \mathrm{p} .1)$. This interest was not in the particular as it represented and imperfectly expressed the ideal, but in the infinitely various shades and textures of the singular itself. Such an absorption in details (which threw Darwin's mind into a "chaos of delight" and provided "evidence visible as well as circumstantial" to the reader of the Illustrated London News) gave value to the unmediated experience of the world, the palpable presence of the real in all its splendid and multifarious variety.

\section{Composition}

The popularity of panoramas and dioramas in the nineteenth century offers the most frequently cited proof of these concerns, since the spectacles "relaxed the tension between the real object and the picture, for they aimed not only at imitating reality but at replacing it," as Werner Hoffman said in The Earthly Paradise (1961:193). I believe that this observation also explains the drive to invent photography-a problem that attracted a host of workers in the early nineteenth century - as well as the century's understanding of its possibilities. Photography, after all, is a medium, not a style; the term assumes certain physical facts of creation (like any other medium), but these in themselves do not dictate how the pictures will look. In other words, the new method of picturemaking did not by its nature overthrow traditional means of composition; rather, the interests the photographs were to answer sometimes demanded new forms of presentation. That certain images consequently came to look unconventional did not cause 


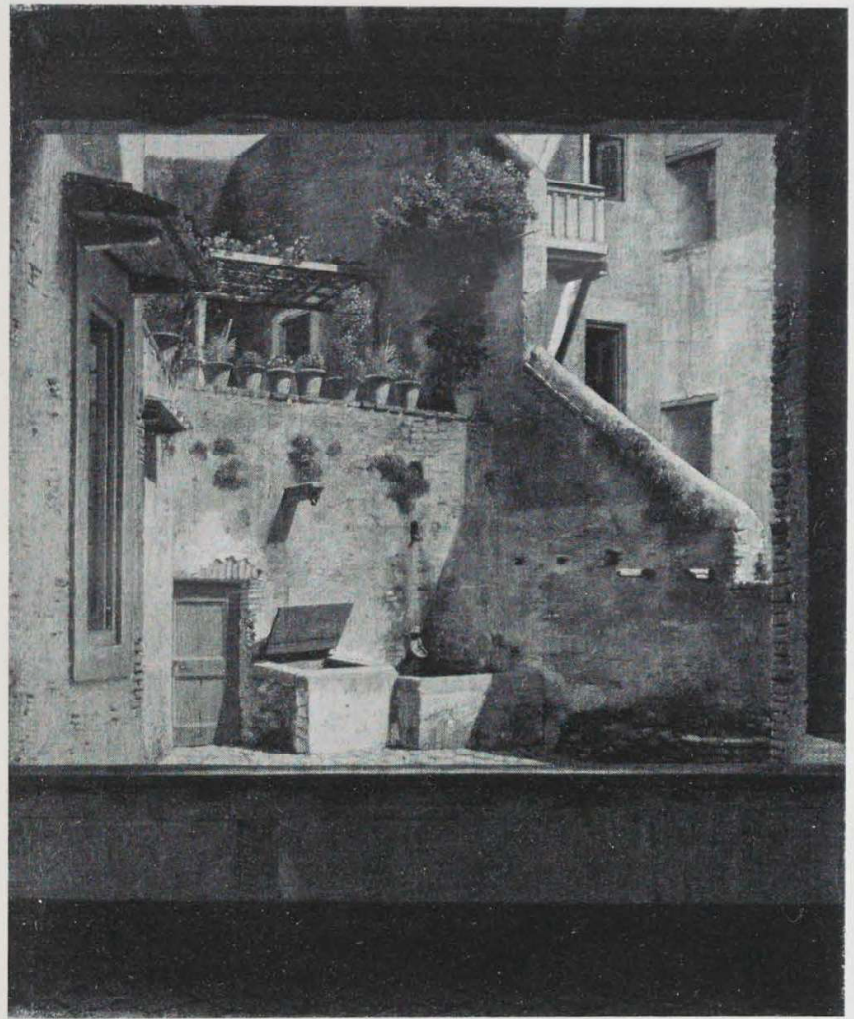

Figure 2 Christoffer Wilhelm Eckersberg. A Courtyard in Rome, 1813-1816. Oil on canvas. Kunstmuseum, Ribe, Denmark.

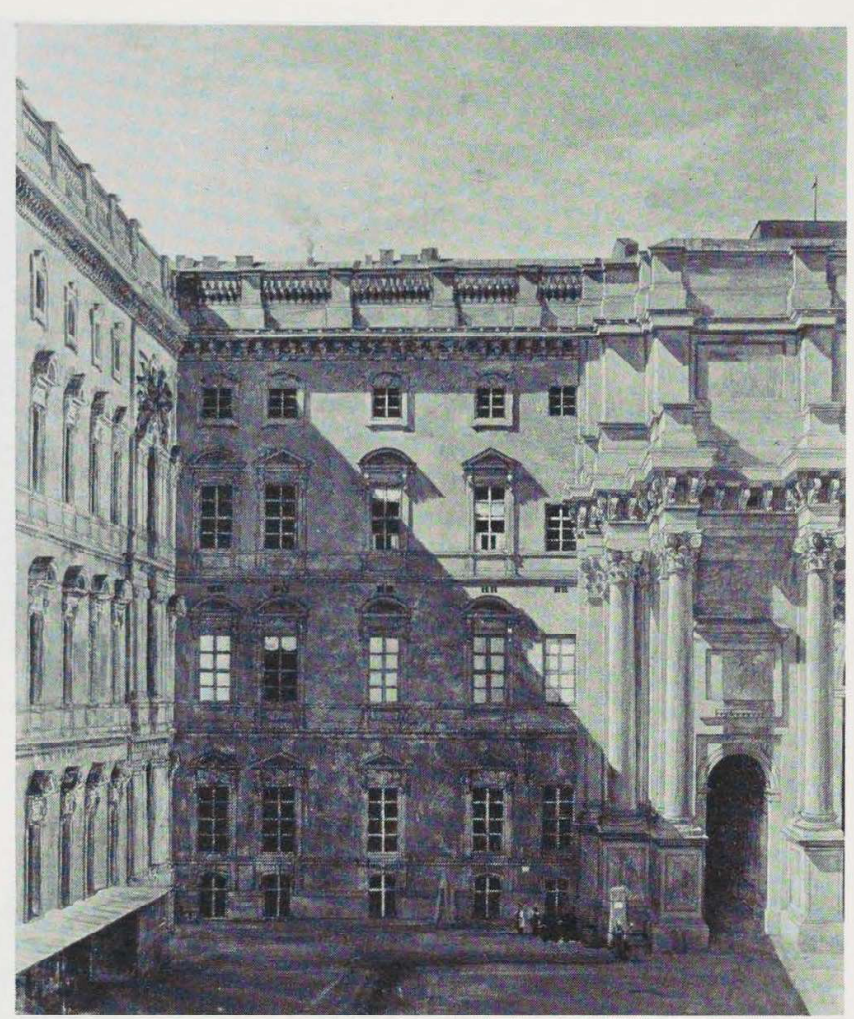

Figure 3 Eduard Gaertner. Corner of the Eosander-Hof, or Outer Courtyard, of the Royal Palace, Berlin, ca. 1831. Oil on canvas. Verwaltung der Staatlichen Schlösser und Gärten, Berlin. particular concern, since they were to be synonymous with their subjects; the picture was successful to the extent that it dissolved into the material it held forth to the viewer.

I propose, then, an understanding of the act of artistic creation as a response to the pressure of a not-yet-seen audience and a fully seen world. Categorically unlike the splendidly isolated Romantic genius, these artists-in important part-worked to establish a relationship between the viewer and the world, not between themselves and their art. Even such highly sophisticated practitioners as Edgar Degas and Henri Le Secq, who never let the viewer forget their presence as creators of the image, make that presence felt while pretending disappearance; they play games with the nature of their role. Degas, for example, constructed pictures that strain but do not break the limits of physical possibility. Thus, his unexpected and often odd compositions excuse themselves by placing blame (as it were) at the door of the world outside. Yet, while claiming by their very plausibility to be passive reports of found configura- tions, the pictures force us to become aware of the artistry of the images by their sharp challenge to the conventional. Henri Le Secq's view of the main portal of Chartres Cathedral's south transept (Figure 1) catapults us into an immediate and dramatic relationship with the entrance, and especially with the aloof and superior figure of Christ who stands far above our heads. At the same time, however, Le Secq's signature across the boards of the door playfully (but pointedly) denies the transparency of the work; this blunt reminder of the artist pulls us out of our absorption in the scene.

Simpler pictures than these attempt to eliminate the tension between the picture and the real object by suppressing traces of the making. A common compositional device, especially in the popular imagery of the nineteenth century, is the inclusion within the final image of the frame which creates the composition. The dark architecture outlining Christoffer Wilhelm Eckersberg's Courtyard in Rome (Figure 2), for example, claims that we saw what he saw, and even more, we stand where he stood, our place measured by the 
Figure 4 Jean-Jacques Tissot. What Christ Saw from the Cross, 18861896. Gouache. (Illustration from Life of Jesus Christ, Paris, 18961897.) The Brooklyn Museum, Brooklyn, New York.

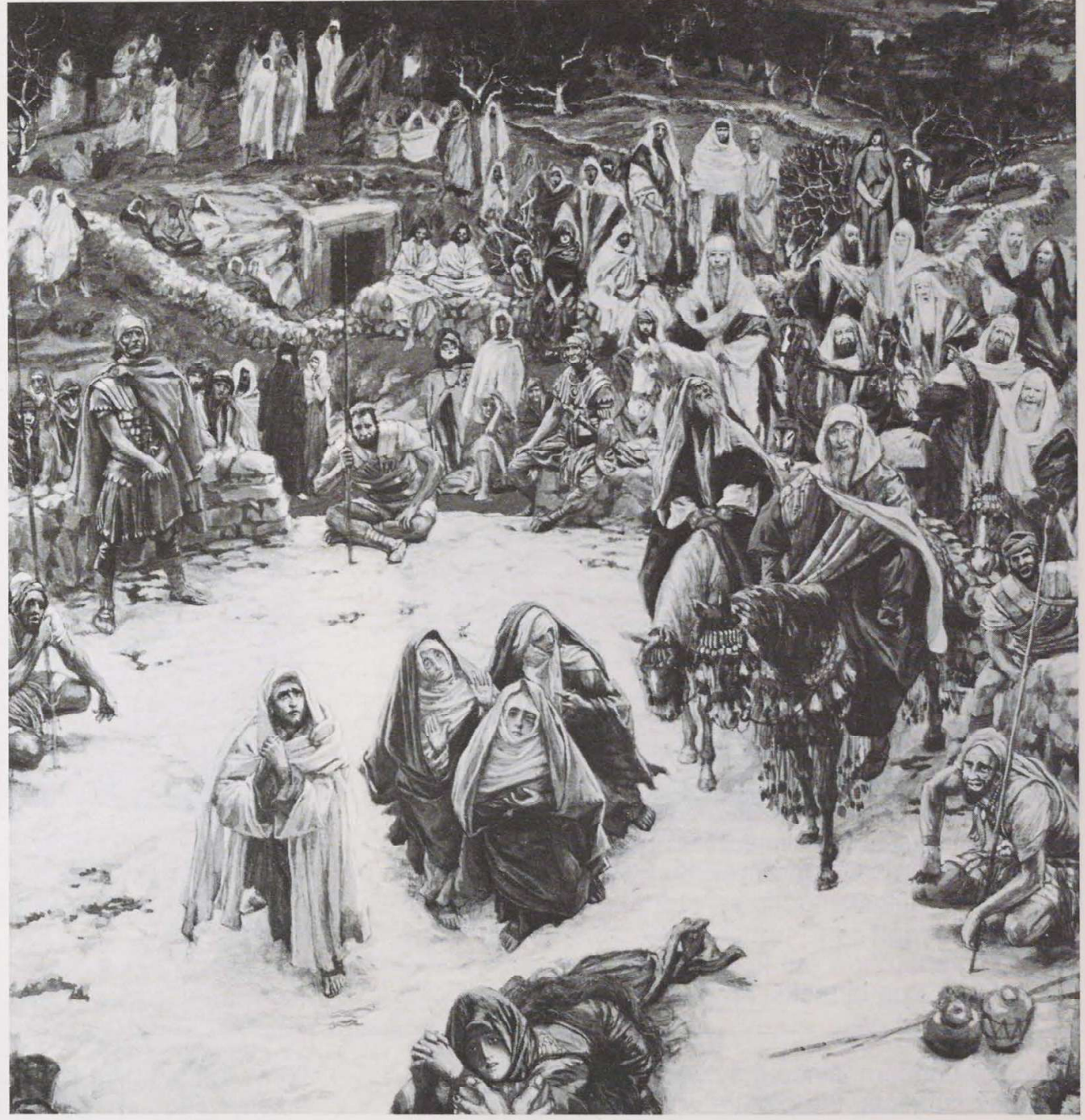

neatly tiled floor of the foreground. Like the roofs so often included at the base of panoramas, the floor and the window frame denote the substitution of the viewer for the artist, as we both become passive ad mirers of what the world presents. Of course, the placement of the viewer need not be articulated so thoroughly. The clarity of the architectural structure in Eduard Gaertner's Corner of the Eosander-Hof, or Outer Courtyard, of the Royal Palace, Berlin (Figure $3)$, for example, compels us to comprehend our relationship to the composition on its terms; we look out the window directly across from (and surely identical in appearance to) the curtained window third from the left on the third floor. Thus both compositions imply that the artist has abdicated, or at least minimized, his role as maker of the image.
Eckersberg and Gaertner respect our distance from their pictures by placing us at a remove from the scene. They involve us in the work, but as spectators rather than participants. We also may become active members, however. Jean-Jacques Tissot's What Christ Saw from the Cross (Figure 4), one of his illustrations to the New Testament, forces us onto the cross itself, and shows with excruciating precision our bloody feet at the bottom of the page. Similarly, View of London from a Painter's Platform (Figure 5), a lithograph published by Rudolph Ackermann in 1829, transforms us into painters of the panorama that filled the Colosseum in London's Regent Park during the 1820 s and 1830 s. Suspended on one of the swinging perches erected before the mammoth canvas, we become creators of a view rather than passive admirers 


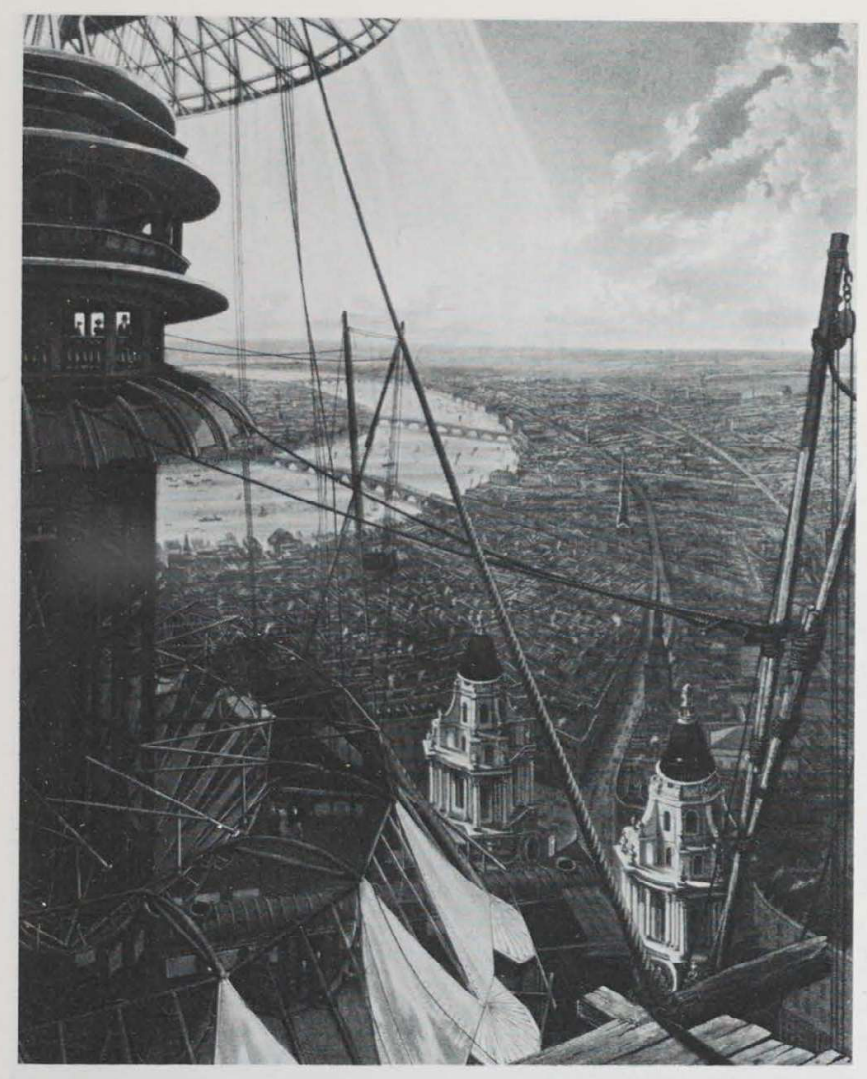

Figure 5 View of London from a Painter's Platform. Colored acquatint and etching. (Plate from Graphic Illustrations of the Colosseum, Regent's Park, published by Rudolf Ackermann, London, 1829.) Yale Center for British Art, Paul Mellon Collection.

of the spectacle, distinguished by our activity from the tiny pecple who look out from the platform atop the pinnacle of the painted St. Paul's Cathedral. ${ }^{3}$

\section{The Presentation of Information}

Composition does not provide the only means of establishing our relationship to the image. These nineteenth-century works of realism commonly describe rich accumulations of detail, which draw us into the picture as we attempt to form a unity from the perhaps discordant and often disparate elements. A picture such as Frederick Mackenzie's detail of the roof of Henry VII's chapel in Westminster Abbey (Figure 6), published in John Britton's Architectural Antiquities of Great Britain (London, 1807), seems shockingly abrupt in its composition. What we with twentieth-century sensibilities understand as pictorial revolution, however, far more likely reflects a desire to convey objective, factual information as compellingly as possible. The suddenness with which the pendant appears before our eyes makes us feel that we see the structure without the interference of reporting: we are there. In addition, though, the sharp, crisp detailing, set off by contrast to the relatively undefined background, plays a vital part in creating the specificity of the object. We read the intricacies of the carving as proof of immediate physical presence, and armed with this assurance we become drawn into making sense of the information presented by the picture.

Johan Christian Dahl's View from Praestø (Figure 7) manipulates the same process on a more ambitious scale. A crisp, clear light, so characteristic of the Northern artists of the period, defines the leaves, the rocks, the grasses, and the tree trunk in hypnotic detail. We become immersed in the reading of these visual facts, trying to shape the parts into the continuity of form that the apparently truthful and complete description persuades us exists. Unlike earlier works such as Albrecht Dürer's Great Piece of Turf (Albertina, Vienna), however, Dahl's view presents the tangle of natural growth as a detail of the whole but not an isolated one. As in Mackenzie's picture of the pendant, our sense of the complexity of the particular gains by contrast to the less precisely defined (but nonetheless visible) context. Dürer's work depicts a single phenomenon which he selected and offered for our attentive but passive inspection. The later artists recorded a point of view, and with it, an experience; they chose the spot on which we stand together.

Understood in this way, the inscriptions John Constable wrote on his cloud studies become critical and revealing elements of the pictures. The notation, for example, on the back of Study of Clouds and Trees (Figure 8) reads: "Hampstead,/Sept. 11, 1821.10 to 11 Morning under the sun/Clouds silvery grey on warm ground/sultry. Light wind to the S.W. fine all day-but rain the night following." This textual commentary, so explicit in its re-creation of the conditions of time and place, substantiates what the style of the painting itself suggests: that the character and position of the cloud determined the picture's look. The trees both locate us and locate it, contributing placement to the description of the particular. These images are less experiments in picture-making than records of an analysis of the world, a generalization about Constable's sketches presumably in accord with his own definition of painting as a science that "should be pursued as an inquiry into the laws of nature" (Constable 1970:69). 


\section{Nineteenth-Century Photography}

Photography seemed perfectly suited to such investigations, since the mechanical functioning of the camera apparently eliminated all possibility of human interference or manipulation. Further, the medium possessed the capacity to reproduce with ease and precision more detail than the eye could perceive. Hence to many viewers the process represented nature, not art. The French critic Jules Janin, for example, wrote that "the daguerreotype is not a picture. . it is a faithful memory of what man has built throughout the world and of landscapes everywhere" (quoted in Newhall and Doty 1962:25-28). William Henry Fox Talbot, one of the inventors of photography, called two of his books The Pencil of Nature (London, 1844) and Sun Pictures of Scotland (London, 1845), descriptions of the medium which his contemporaries accepted for general use. ${ }^{4}$ Sometimes the photographs even seemed to offer a more complete experience than that presented by the world itself. Eugène Viollet-le-Duc (1866:33), for example, wrote that one could never take too many photographs while restoring works of architecture, since "one often discovers in a print what one did not perceive in the thing itself." Others similarly remarked on their fuller perception of the world when seen through the eye of the camera. $^{5}$

\section{Portraits}

Photographic portraiture surely provides the most convincing demonstration of the extent to which even we, the modern viewers, confuse these patently created images with their subjects, and hence their analysis illuminates the process of our viewing such images. There is still, a century and a half after the invention of photography, an instinctive belief in the photographic portrait as something more than simply a pictorial depiction of the subject. André Bazin discussed this belief in "The Ontology of the Photographic Image"

A very faithful drawing may actually tell us more about the model, but despite the promptings of our critical intelligence, it will never have the irrational power of the photograph to bear away our faith. ... Hence the charm of family albums. Those grey or sepia shadows, phantomlike and almost indecipherable, are no longer traditional family portraits but rather the disturbing presence of lives halted at a set moment in their duration, freed from their destiny; not, however, by the prestige of art but by the power of an impassive mechanical process. [Bazin 1967:14]

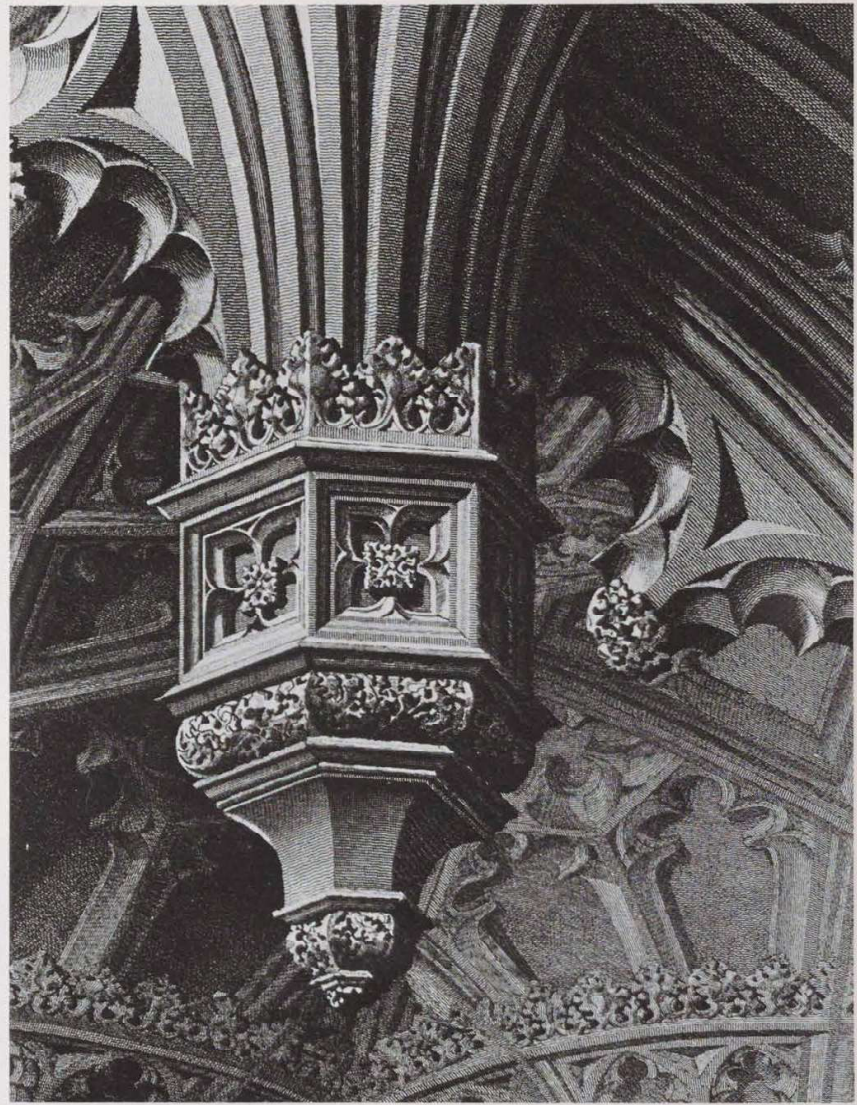

Figure 6 Frederick MacKenzie. Henry VII's Chapel. Engraving and etching. (Plate 6, The Architectural Antiquities of Great Britain, by John Britton, vol. 1, London, 1807.) Avery Architectural Library, Columbia University, New York. 


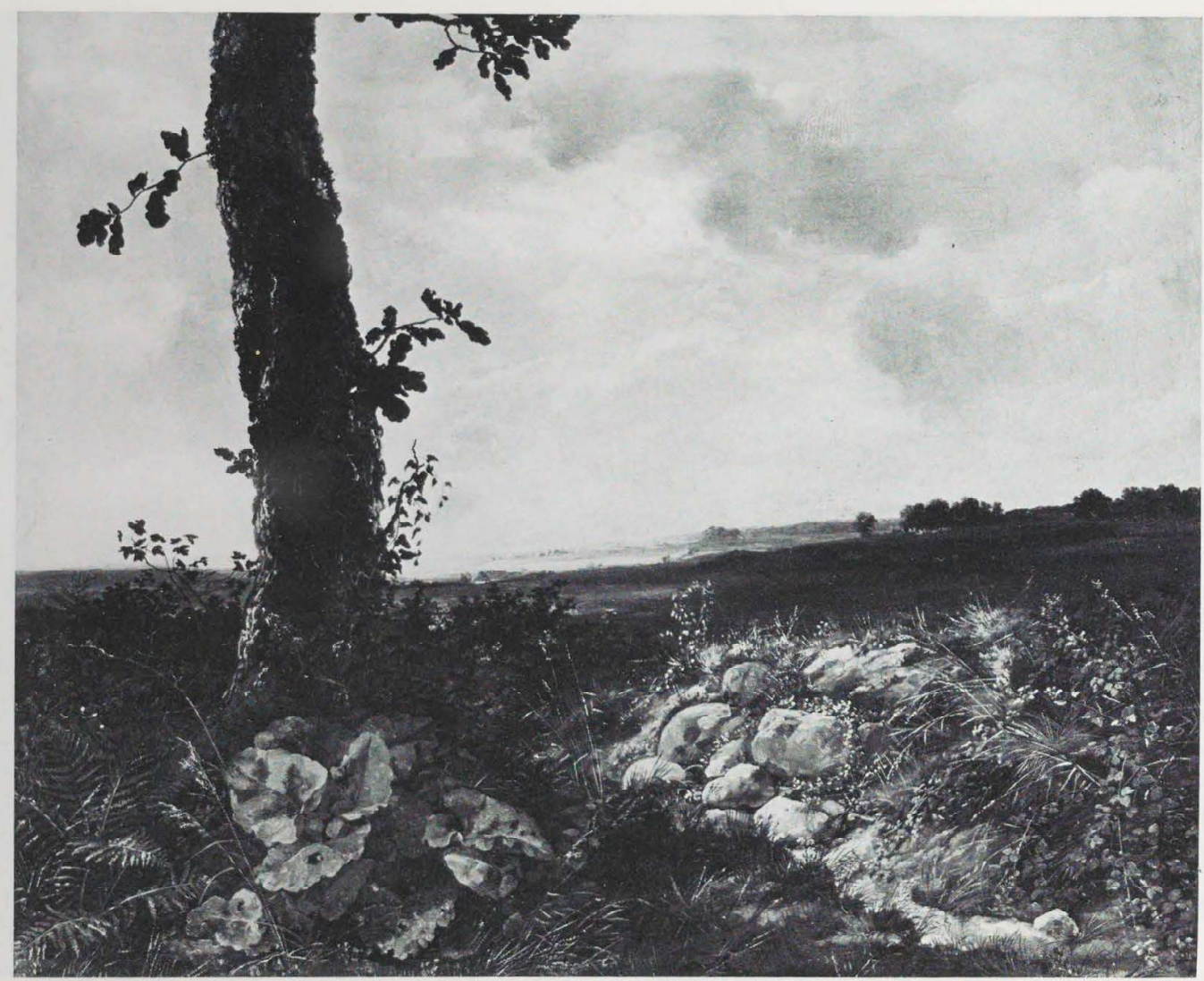

Figure 7 Johan Christian Dahl. View from Praestø, ca. 1814. Oil on canvas. Nasjonalgalleriet, Oslo.

Bazin's term "irrational power" is apt and is amply demonstrated by stories from the last century as well as our own responses. Richard Rudisill (1971:218; Chapter 8 , passim), for example, has analyzed midnineteenth-century America's faith in the camera's power, which even extended to the near creation of life itself. More than one sitter believed that the very act of photographing could endow the inanimate or absent with a full physical presence, and many employed it to photograph dead children, producing images which were to preserve the subjects as living, not dead, beings.

The basic formative component of most nineteenthcentury photographic portraits is random, unexpected, and seemingly infinite detail. Taken together, these bits of information provide (as Lady Eastlake so perceptively remarked) "accurate landmarks and measurements for loving eyes and memories to deck with beauty and animate with expression, in perfect certainty that the ground plan is founded on fact" (quoted in Arts Council of Great Britain 1972:10). Lady Eastlake's decking and animating describe an intensified version of the process of empathetic pro- jection that occurs with any portrait. Our active response to the apparently disparate facts offered by the picture shapes a convincing individual presence. We simultaneously become drawn into a specificity of time and of place, the necessary dimensions in which a particular person exists. The interior time of the image (which contains both person and place) merges with the exterior time of the viewer, so that the discrete entity of the work appears to be broken open and the relationship with the subject of the picture charged with intensity. Unlike our replacement of Christ in Tissot's What Christ Saw from the Cross, we are here apparently involved in a reciprocal relationship, and our tension during viewing comes from the maintaining of this exchange.

What such photographs offer as the conclusion of active viewing is the illusion of an immediate and tangible physical presence. It is this combination of the authenticity created by active viewing with the authenticity derived from faith in the photographic process that results in the extraordinary power of photographic portraits. Southworth and Hawes's portrait of one of Hawes's daughters (Figure 9) beauti- 


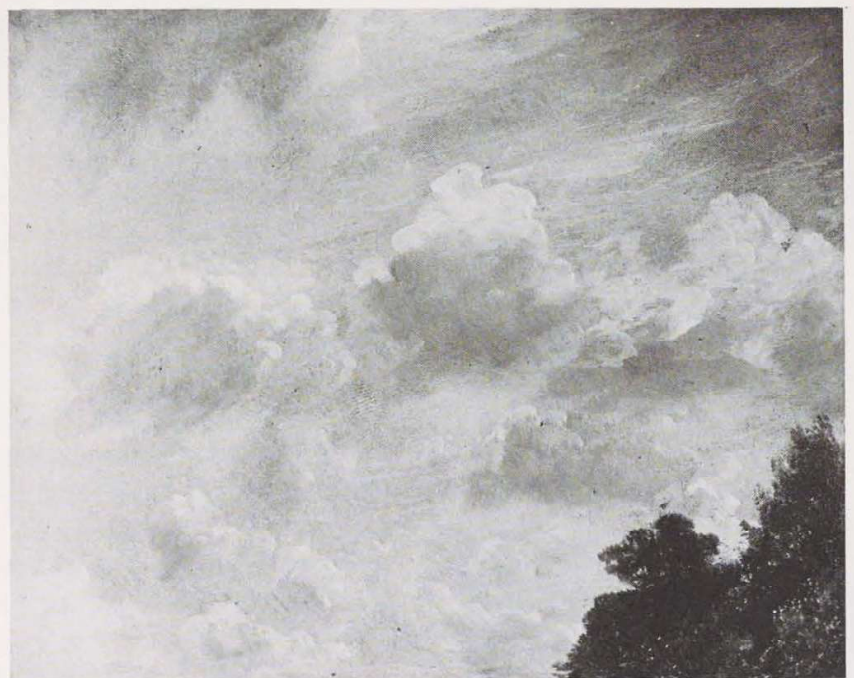

Figure 8 John Constable. Study of Clouds and Trees, 1821. Oil on paper, mounted on board. Royal Academy of Arts, London.

Flgure 9 Albert Sands Southworth and Josiah Johnson Hawes. Marion Augusta Hawes or Alice Mary Hawes, ca. 1855-1860. Daguerreotype. International Museum of Photography at George Eastman House, Rochester, New York.

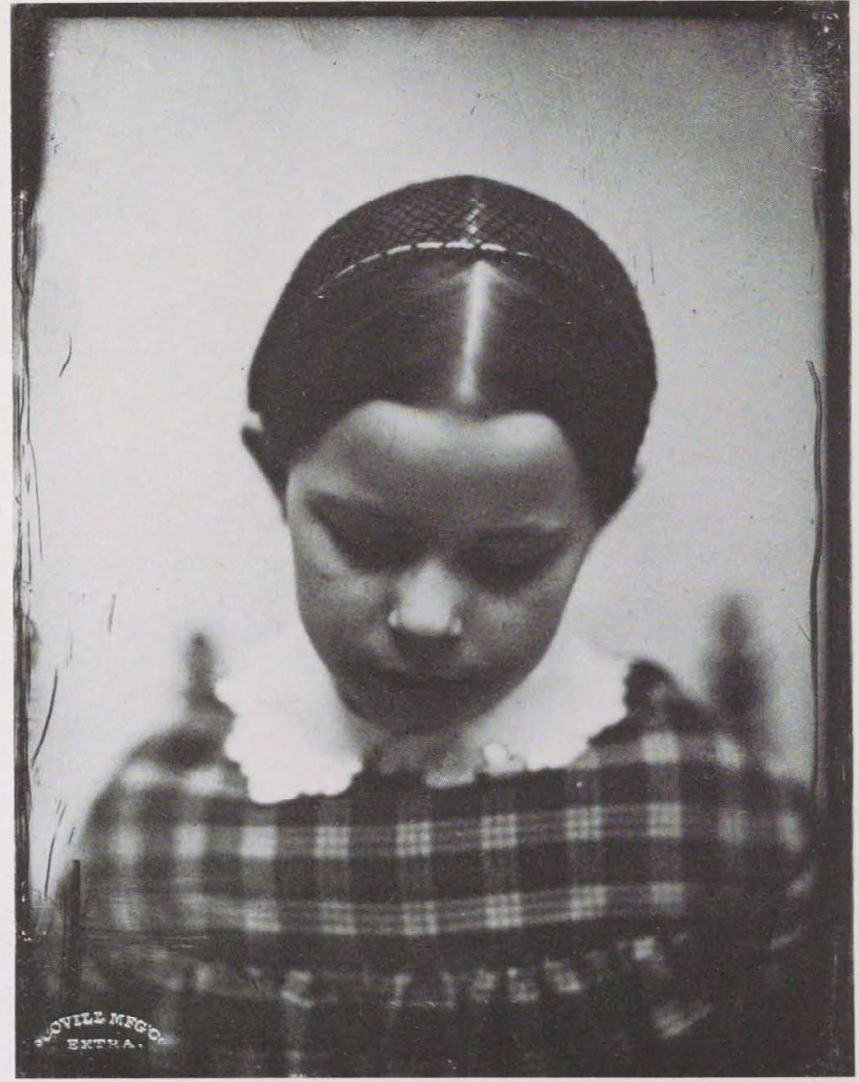

fully illustrates this process. The disarming casualness of the child's pose and the intimacy implied by her apparent lack of awareness of us create an affecting and compelling image, but one that works precisely by denying its status as a consciously formed image. Our faith arises from its innocence, its claim to a lack of manipulation of the medium and the subject to produce a picture. At the same time, however, its consummate mastery becomes clear to any careful viewer: we are held spellbound through the calculations of the artist. Unlike so many anonymous snapshots, which charm by their awkwardness and even incompetence, this daguerreotype only pretends informality and chance.

\section{Events and Places}

Mid-century photographs of events, or of the places where events occurred, also exploit incidental detail in a similar fashion. The random disorder of dead bodies scattered across the ploughed field in Felix Beato's Charge of the Dragoon's Guard at Palichian (Figure 10) persuades exactly because it is not expected. This accidental quality testifies to the reliability of the evidence while absorbing us in the effort of assimilating all that detail into comprehensible form. Similarly, Humphrey Lloyd Hime's Prairie on the Bank of the Red River, Looking South (Figure 11) - a title which precisely locates us in a landscape where precision would seem to have no meaning - claims authority from the very absence of information: how could such banality contain falsehood? Maxime Du Camp's Profile of the Great Sphinx, from the South (Figure 12) also commands assurance but in a reverse manner. Confronted by a subject that bristled with conventional viewpoints, Du Camp photographed from an unfamiliar position and included such defiantly disfiguring elements as the large splotch of shadow sprawled across the sand. The result is un- 
Figure 10 Felix Beato. Charge of the Dragoon's Guard at Palichian, China, 1860. Albumen print. The Museum of Modern Art, New York. Purchased as the Gift of Shirley C.

Burden and the Estate of Vera Louise Fraser.

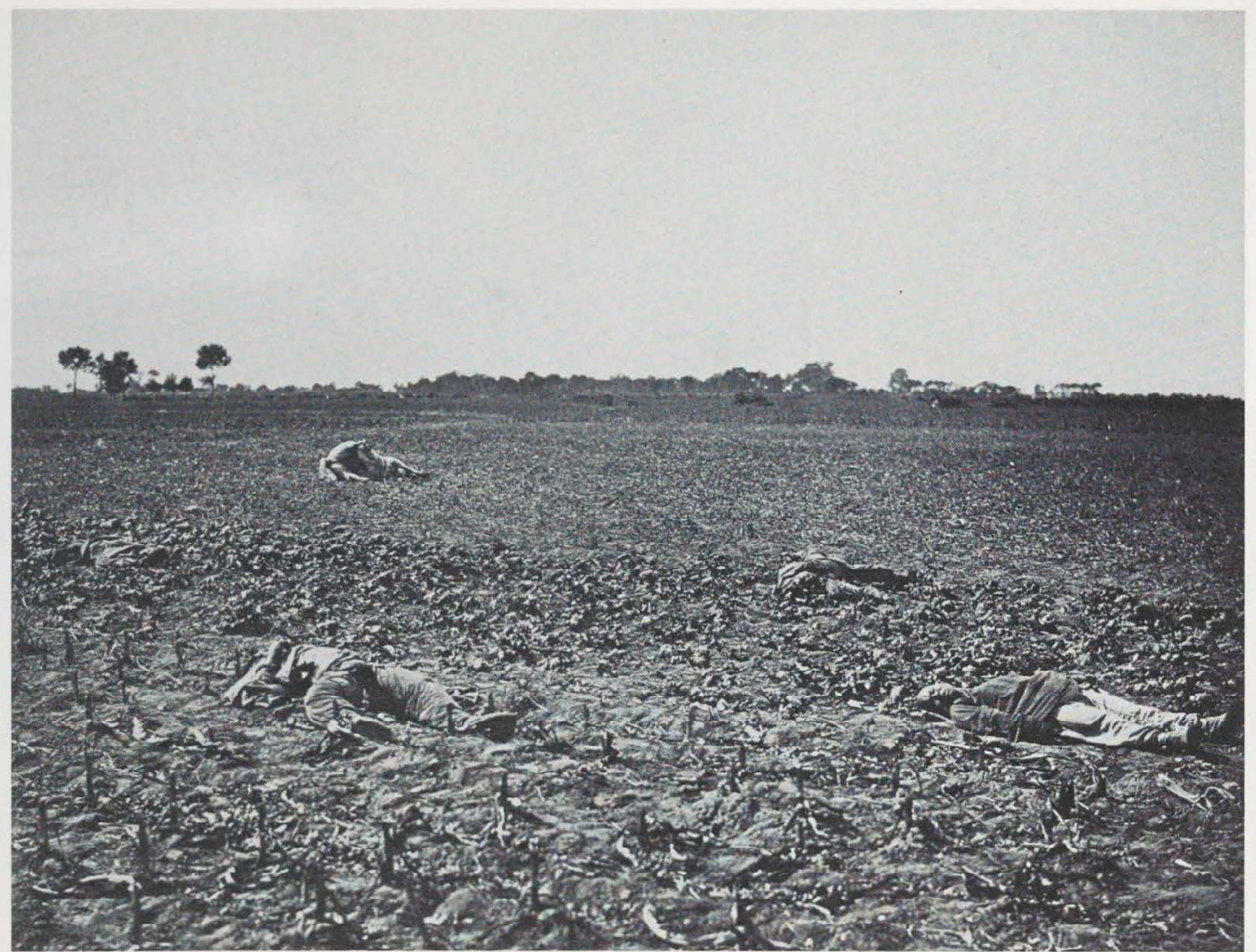

mistakably jaunty-having a great time, wish you were here-and the picture becomes both proof of Du Camp's experience and a means of substitute experience for us.

Such readings of these and many other photographs consistently suggest that the images - like the contemporary pictures discussed above-came into being less to explore the pictorial innovation that seems so striking to us than to satisfy an insatiable desire for vivid and compellingly immediate descriptions of the physical world. Further, the same values can be found in works that do not employ formal innovation. I would argue, in fact, that most photographs (like most paintings) of the nineteenth century at least attempted to stay within the bounds of conventional pictorial construction. Their compositional instinct might be characterized as pointing at the object of interest rather than carving pictorial coherence out of the continuous flow of the world. Not surprisingly, then, both the fascination and the possible formal oddities of many photographs come from their detail rather than their structure.
Carleton Watkins, for example, one of the greatest of the century's photographers, judiciously centered his majestic trees in the middle of mammoth glass plates. California Buckeye (Figure 13) is typical: framed symmetrically by smaller, less significant masses of leaf, the buckeye bursts with an abundance of growth. The spectacle of the tree commands our attention; we become involved in the inspection, the treasuring, of such glorious proof of natural fecundity. That the work also lops off forms at the edge of the composition seems quite incidental to its primary purpose, and in pictures such as this one it seems downright perverse to suggest that the dominant concern of the photographer lay with anything other than the tree itself. (That we may choose to respond to other qualities - the odd effect of the light on the white walls of the cabin, for example - is a different issue, of course.)

Photographs also may be ordered with a formal logic that permits perfectly traditional pictorial analysis. A harbor scene by Gustave Le Gray (Figure 14), for example, delights with its sequence of echoing shapes that unfold from the center of the image, a 


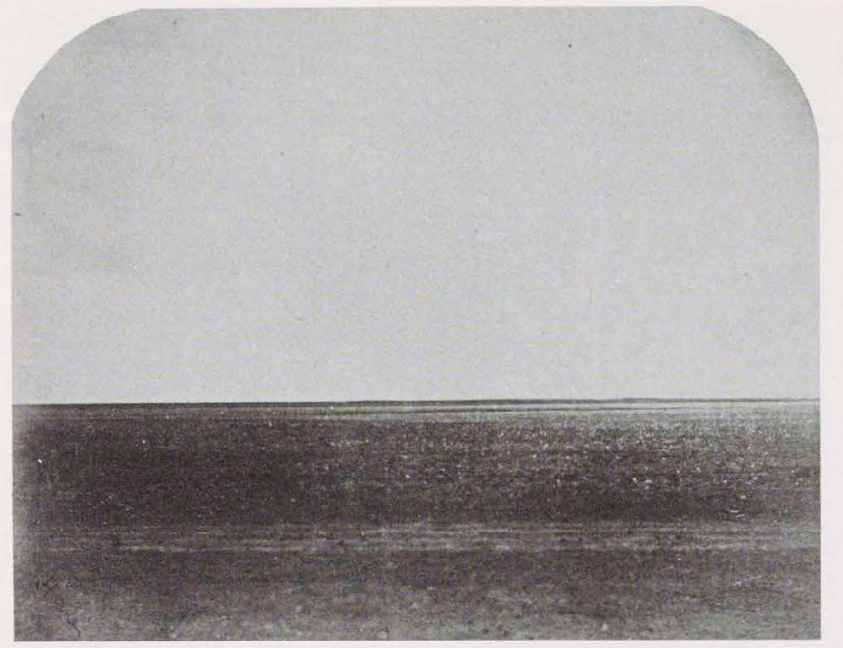

Figure 11 Humphrey Lloyd Hime. The Prairie on the Bank of the Red River, Looking South, 1858. Albumen print. The Notman Photographic Archives, McCord Museum, Montreal.

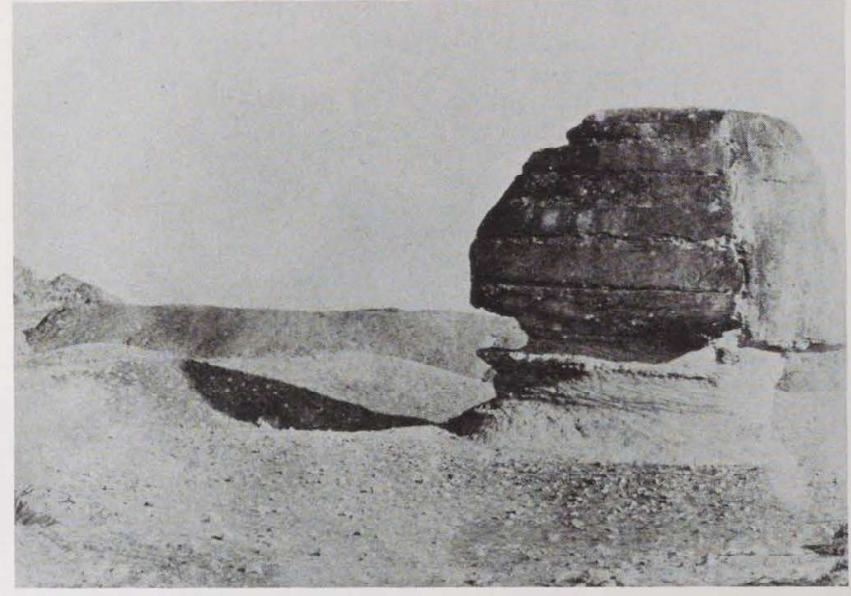

Figure 12 Maxime Du Camp. Profile of the Great Sphinx, from the South, 1849-1851. Salt print. Courtesy of the Gilman Paper Company Collection. structure that visually disciplines the bustle and disorder of Honfleur's harbor into something stable and calm. Further, the formal principles used by Le Gray, as well as the compositional structure achieved, do not stray so far from the limits of art as he would have learned them as an art student, even if his means of arriving at them necessarily differed. Yet just as the extraordinary spectacle of the buckeye tree bursts out of Watkins's centered, balanced composition, so here too the fascination of the accumulated detail and, perhaps even more, the mundaneness of the ladder that fixes and focuses the composition, mark the work as different from the ordinary product of art school. Similarly, Charles Leander Weed's River Scene in Nagasaki, Japan (Figure 15) presents an alien landscape as if it were a familiar spot of British picturesque scenery. Entirely obedient to the strictures of writers such as the Reverend William Gilpin, the river winds back into space, the mountains and the trees close the horizon with gentle, misted curves, and the houses, rocks, and leaves repeat these windings and curvings. Nonetheless, the mammoth albumen print rivets our attention in a way quite unlike the usual watercolor or drawing of the picturesque landscape. We become hypnotized by the seemingly infinite vari- ety of texture and shape, and slowly the restraint of the composition breaks down before the richness of the information.

Other photographs mask their formal order with the immediacy of the subject. Robert Macpherson's Broken Arches in the Colosseum (Figure 16), for example, pulls the complicated forms and surfaces into a tight and stable composition, while surprising us with the sudden, forceful presence of the ruins. The particulars inform the specialist and the Roman, both of whom can gather enough information about the far and the near to locate themselves precisely. For the ordinary viewer, though, Macpherson's photograph pleases with its description of the worn, overgrown stones and the repetition of shapes between foreground and background, light and dark. Most of all, we delight in the sense of being there, standing within the shadow of the bright Roman sun where the gladiators once waited for their appearance within the arena. Just as Weed's river scene appeals to the established category of the picturesque, so this view of classical ruins assumes that such sights thrill our imagination with their testament about the grandeur of a valued past. And for those who could not live in Rome, such a large, handsome photograph provided the next best thing. 


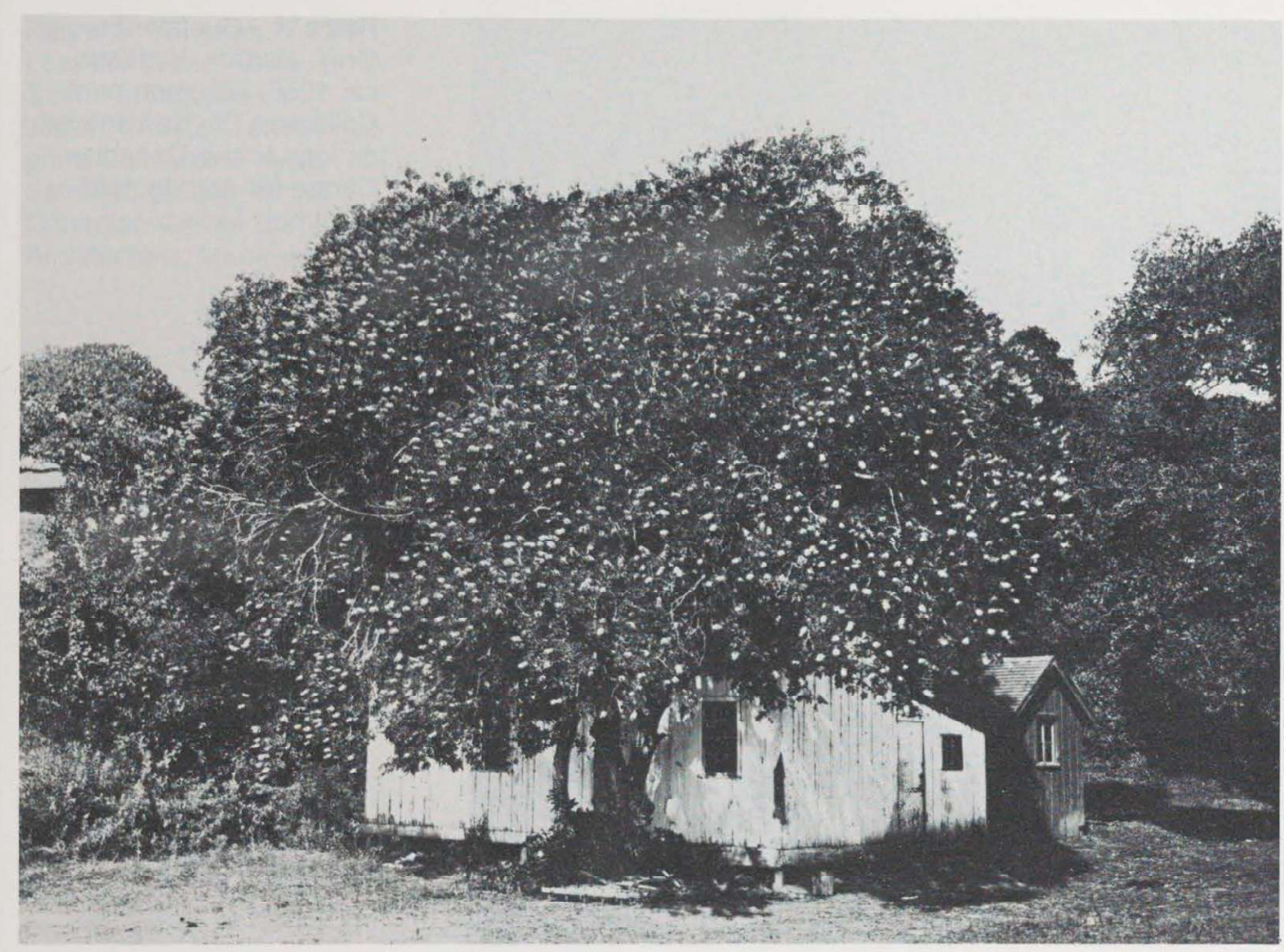

Figure 13 Carleton E. Watkins. California Buckeye, 1860s. Albumen print. Collection Phyllis Lambert, on loan to the Canadian Centre for Architecture, Montreal.

\section{Sale and Presentation}

The original history of many of these images confirms the notion that the photographers kept a general audience firmly in mind. Most of the photographers already mentioned both exhibited and sold their work to the public. The photographs by Watkins, Weed, and Macpherson illustrated here, for example, were offered for sale through studios or dealers. The photograph by Maxime Du Camp of the Sphinx, on the other hand, did not appear in Egypte, Nubie, Palestine et Syrie (Paris, 1852), which used a neatly and far more conventionally ordered depiction of the Sphinx and the pyramids lined up along the horizon (Figure 17). Establishing these distinctions is important, since the original context of any work reveals something about its history and quite possibly, therefore, its making. In the case of photography, this general principle of research gains additional force, since the lack of an adequate history of the material increases the danger of confusing our response with that of the photographer. Further, photographs indicate less about their character than works in more traditional media; perceptible differences of form and style generally distinguish private sketches from paintings intended for public display, for example. Although study of the work of certain photographers may reveal such distinctions - the presence of a signalure, perhaps, or of an elaborate mount-one cannot expect them.

The original forms of presentation often provided an important context as well. Le Secq's view of the portal of Chartres, for instance, appeared as one plate in Fragments d'architecture et sculpture de la cathédrale de Chartres d'après les clichés de M. Le Secq, artiste peintre, a portfolio of photolithographs published in the late 1870s, some 25 years after Le Secq made the original paper negatives. ${ }^{6}$ Although highly individual and certainly unconventional in choice of viewpoints, the collection presents a beautiful and often very moving description of the Gothic cathedral as an architectural, sculptural, and also spiritual construction. Another plate from the same portfolio (Figure 18) perhaps suggests the extent of Le Secq's concern for conveying the quality of place. Just as he showed the doorway as we would experience it at the Cathedral, so he presents these columnar figures on the north porch emerging from the turn of the portal as we ourselves round the corner. Graceful and serene, they seem to transcend their gross stone nature as they look out at the temporal, material world that lies before them. We, their admirers and audience, can only hope to achieve similar beautitude. 


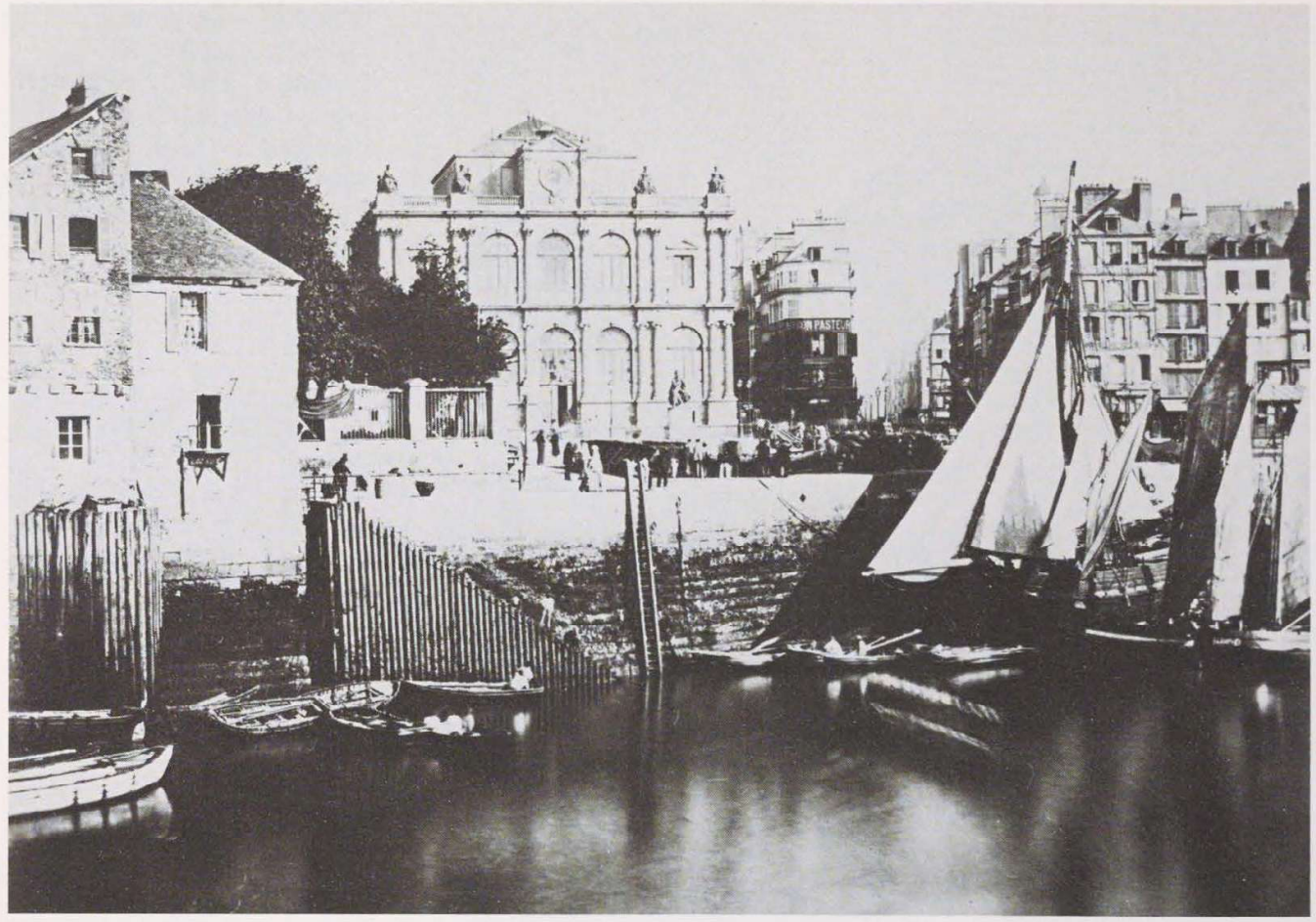

Flgure 14 Gustave Le Gray. Harbor, Honfleur, ca. 1855. Albumen print. Collection Phyllis Lambert, on loan to the Canadian Centre for Architecture, Montreal.

Reconstruction of the original context also may turn an apparently exceptional picture into a perfectly explicable work. An example of such a transformation is William James Stillman's Profile of the Eastern Facade, Showing the Curvature of the Stylobate (Figure 19), plate 17 of The Acropolis of Athens Illustrated Picturesquely and Architecturally in Photography (London, 1870). Stillman's full caption explains the striking boldness of the detail, which illustrates a recently discovered and at that time still controversial aspect of the Parthenon's structure. ${ }^{7}$ The viewpoint Stillman chose offered the best position from which the deformity could be seen, despite the difficulty we have in making it out. (Ironically, the curvature cannot be photographed convincingly, although drawings and measurements describe it with clarity.) Once again, therefore, the photographer seems to have been concerned with the depiction of the world before the making of art, and the medium employed as something that provided transparency, the invisibility of the perfectly accurate transcription of the subject.

\section{The Photographers' Analysis}

Finally, perhaps, the clearest evidence of the period's understanding of the medium comes from the analysis offered by the most sophisticated of the photographers themselves, who reveal the period's aesthetic tastes and needs in their descriptions of the workings of the process. Unlike the ordinary critic or viewer, these photographers easily distinguished the formed image from its subject, recognizing the capacity of the photograph to express the vision of the maker as well as the physical facts of the thing represented. Revealingly, they did not discuss photography as something new and revolutionary. Rather, the medium seemed an efficient means of depiction that could be controlled with assurance and made to serve all manner of projects. Underlying all their discussions is the assumption that the most challenging task for the artist is to describe the world as fully and as compellingly as possible. The artistry of the image must not obscure the subject of the depiction. Charles Nègre, writing in the 1850s about his photographs of historical buildings in the south of France, eloquently expressed these ideas: 
Figure 15 Charles Leander Weed. River

Scene in Nagasaki, Japan, 1867. Albumen print. Collection Phyllis Lambert, on loan to the Canadian Centre for Architecture, Montreal.

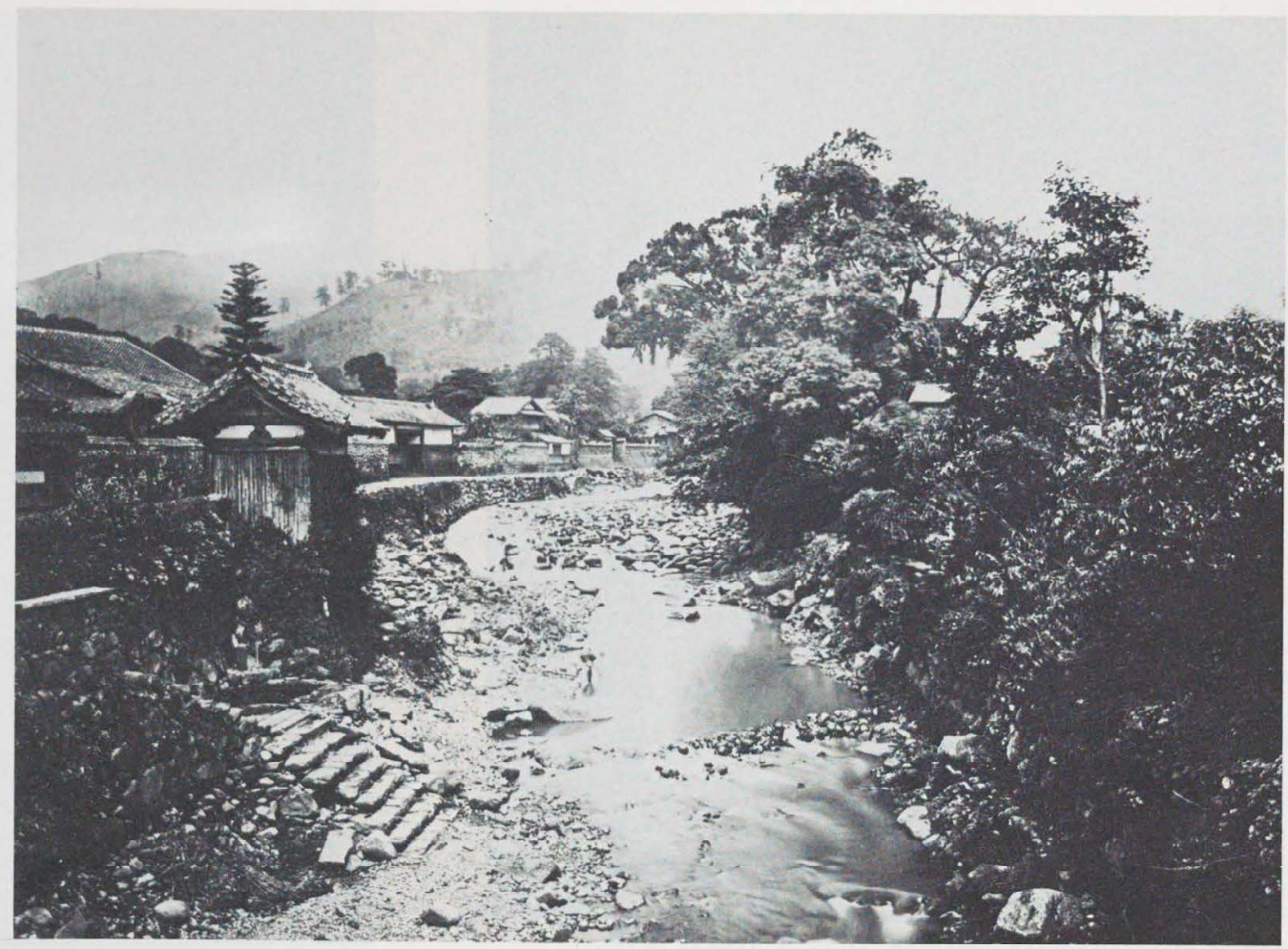

Photography is not a remote and barren art; it is, in fact, a rapid, sure, and uniform means of working, which is at the artist's service, and which can thus reproduce with mathematical precision the form and the effect of objects as well as that poetry which is the immediate result of all harmonious combinations. It is not only the varied and picturesque nature of the sites, the brightness of the sun, the purity of the atmosphere that I wished to show in my photographs; in addition to the beauties with which the Creator has endowed our climes and which stem from completely physical causes, I have searched for beauty of another order which also should be of importance to us because it relates to the study of art and history. Each generation has left a visible trail of its passage across the face of the earth - such as religious monuments, public or private-and it is through the study of these monuments that, today, we may form an exact idea of the various civilizations. [Borcoman 1976:6]

\section{Acknowledgments}

I would like to thank Peter Galassi, of The Museum of Modern Art, New York, and J. Kirk T. Varnedoe, of New York University, both of whom contributed greatly to my thinking about the issues I discuss. I also would like to thank Richard Brilliant, of Columbia University, with whom I developed the understanding of the process of viewing photographs that I analyze here, and who generously criticized this article while it was still in draft form. 


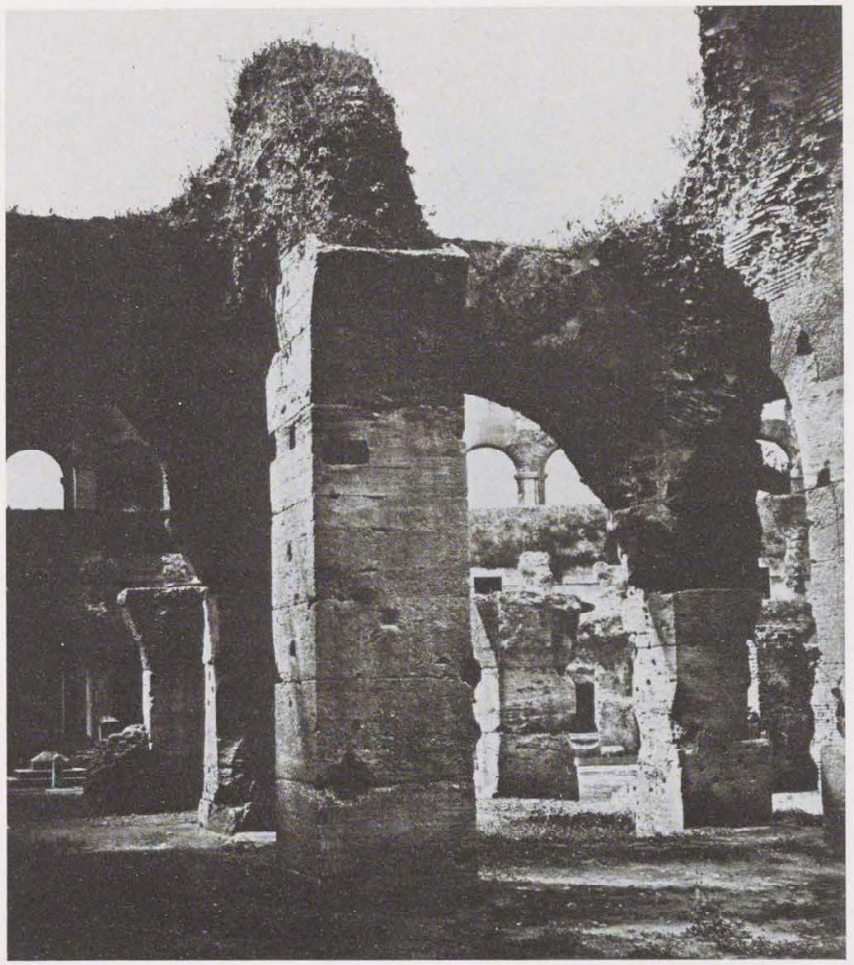

Flgure 16 Robert Macpherson. Broken Arches in the Colosseum, before 1860. Albumen print. Collection Phyllis Lambert, on loan to the Canadian Centre for Architecture, Montreal.

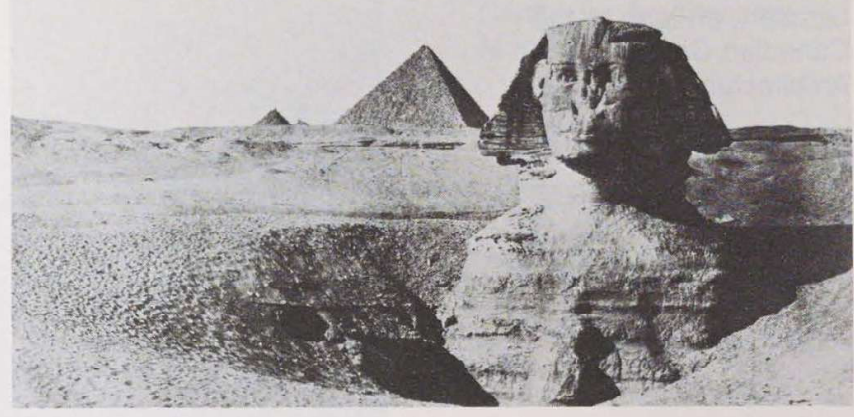

Figure 17 Maxime Du Camp. Le Sphinx. Salt print. (Plate 11, Egypte, Nubie, Palestine et Syrie: Dessins photographiques recueillis pendant les années 1849, 1850 et 1851, Paris, 1852). Collection Phyllis Lambert, on loan to the Canadian Centre for Architecture, Montreal.

Figure 18 Henri Le Secq. Chartres Cathedral, Old Testament figures, North Porch, 1852. Photolithograph. (Plate from Fragments d'architecture et sculpture de la cathédrale de Chartres d'après les clichés de $M$. Le Secq, artiste peintre, Paris, late 1870 s, from negative made in 1852.) Collection Phyllis Lambert, on loan to the Canadian Centre for Architecture, Montreal.

\section{Notes}

1 Quoted in the Times Literary Supplement, January 16, 1981, p. 57 from the journal Darwin kept during his first trip to the tropics.

2 I will discuss certain aspects of Turner's concern for involving the viewer in the depicted scene, particularly as it relates to his ideas about the nature of art and the artist, in my dissertation, "J. M. W. Turner's Reputation, 1800-1819," which is being written under the supervision of Allen Staley, Columbia University.

8 For a discussion of Ackermann's prints as well as the panorama itself, see Altick (1978:141-150)

4 Any survey of mid-nineteenth-century criticism indicates that Talbot selected his titles from commonly used terms of reference.

5 See also, for example, the description of Baron Gros's discovery of an antique statue he had overlooked on the Acropolis itself-"Le microscope a permis de relever ce document precieux, revélé par le daguerreotype, à sept cents lieues d'Athenes," La Lumière 1 (Feb. 9, 1851), p. 3

6 Ten plates from the portfolio are reproduced in Buerger 1980.

7 There is still today disagreement about how to understand the systematic deviations of the Parthenon. See, for example, Pollitt 1973:74-78. The depiction of the Parthenon in the nineteenth century is to be the subject of an exhibition at the Canadian Centre for Architecture, Montreal.

\section{References}

- Altick, Richard D.

1978 The Shows of London. Cambridge, Mass.: Harvard University Press.

- Arts Council of Great Britain

1972 "From Today Painting Is Dead": The Beginnings of Photography. Exhibition catalog. London.

- Bazin, André

1967 The Ontology of the Photographic Image. In What is Cinema? Hugh Gray, tr. and ed. Berkeley and Los Angeles: University of California Press.

- Borcoman, James

1976 Charles Nègre, 1820-1880. Exhibition catalog. Ottawa: National Gallery of Canada.

- Buerger, Janet $\mathrm{E}$.

1980 Le Secq's "Monuments" and the Chartres Cathedral Portfolio. Image 23(1) (June).

- Constable, John

1970 Lecture 3. In John Constable's Discourses, Vol. 14. R. B Beckett, ed. Ipswich: Suffolk Records Society.

- Galassi, Peter

1981 Before Photography. New York: Museum of Modern Art. 


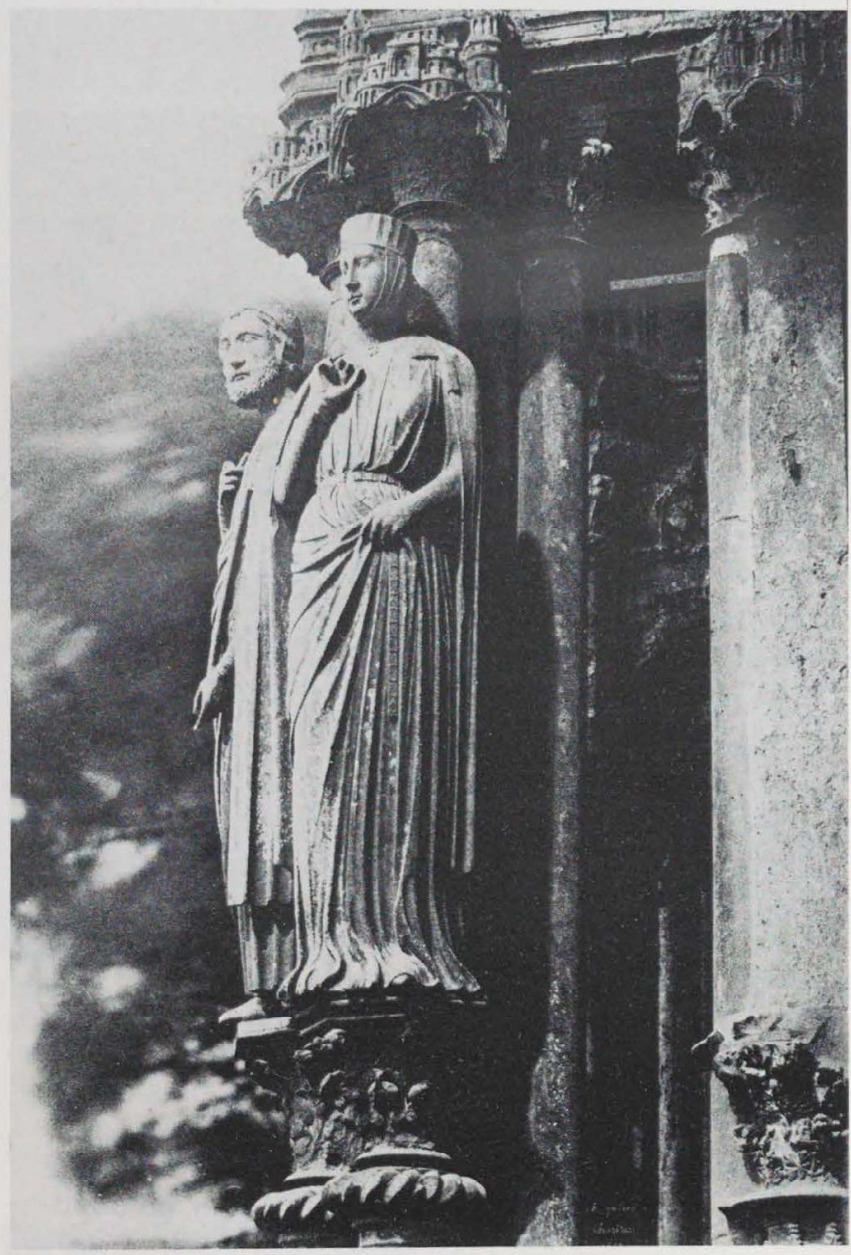

- Hoffman, Werner

1961 The Earthly Paradise: Art of the Nineteenth Century. Brian Battershaw, tr. New York: Brazillier

- Newhall, Beaumont, and Robert Doty

1962 The Value of Photography to the Artist, 1839. Image 11(6):25 28.

- Pollitt, J. J.

1973 Art and Experience in Classical Greece. Cambridge, Mass. Harvard University Press.

- Rudisill, Richard

1971 The Mirror Image: The Influence of the Daguerreotype on American Society. Albuquerque, N.M.: University of New Mexico Press.

- Snyder, Joel

1982 Review of Peter Galassi's Before Photography. Studies in Visual Communication 8(1) (Winter).

- Viollet-le-Duc, Eugène

1866 Dictionnaire raisonné de l'architecture française du Xle au XVle siècle, Vol. 8. Paris.

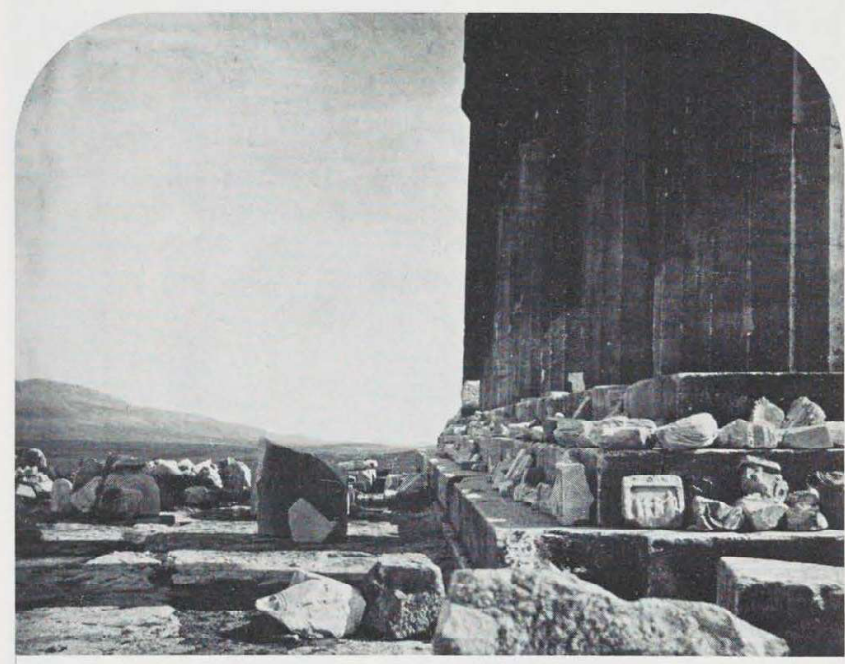

Figure 19 William James Stillman. The Parthenon, Athens, Profile of the Eastern Facade (showing the curvature of the Stylobate), 1868-1869. Carbon print. (Plate 17, The Acropolis of Athens IIlustrated Picturesquely and Architecturally in Photography, London, 1870.) The Museum of Modern Art, New York. Gift of Miss Frances Stillman. 